RURAL DEVELOPMENT IN TROPICAL AFRICA 
By the same editors

Judith Heyer, D. Ireri and J. Moris, Rural Development in Kenya

Judith Heyer, J. K. Maitha and W. M. Senga (eds), Agricultural Development in Kenya: An Economic Assessment

E. de Kadt and Gavin Williams (eds), Sociology and Development

G. Williams (ed), Nigeria: Economy and Society 


\section{RURAL DEVELOPMENT IN TROPICAL AFRICA}

Edited by

Judith Heyer, Pepe Roberts and Gavin Williams

Preface by

Keith Griffin

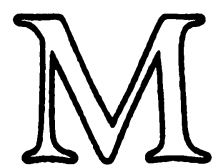


Chapters 3 and 13 appeared in Review of African Political Economy, 10

Selection and editorial matter (C) Judith Heyer, Pepe Roberts and

Gavin Williams 1981

Chapter 1 (C) Judith Heyer, Pepe Roberts and Gavin Williams 1981

Chapter 2 (C) Gavin Williams 1981

Chapter 3 (C) Andrew Coulson 1981

Chapter 4 (C) Judith Heyer 1981

Chapter 5 (C) Michael Cowen 1981

Chapter 6 (C) Bjorn Beckman 1981

Chapter 7 (C) Andrew Shepherd 1981

Chapter 8 (C) Pepe Roberts 1981

Chapter 9 (C) Tom Forrest 1981

Chapter 10 C Roger King 1981

Chapter 11 (C) Tina Wallace 1981

Chapter 12 (C) Tony Barnett 1981

Chapter 13 (C) Adrian Adams 1981

Softcover reprint of the hardcover 1st edition 1981 978-0-333-28448-3

All rights reserved. No part of this publication may be reproduced or transmitted, in any form or by any means, without permission

First published 1981 by

THE MACMILLAN PRESS LTD

London and Basingstoke Companies and representatives throughout the world

ISBN 978-1-349-05320-9 ISBN 978-1-349-05318-6 (eBook) DOI 10.1007/978-1-349-05318-6

Photoset in Great Britain by REDWOOD BURN LIMITED Trowbridge \& Esher 


\section{Contents}

List of Maps vi

Preface by Keith Griffin vii

Notes on the Contributors ix

1 Rural Development Judith Heyer, Pepe Roberts and Gavin Williams 1

2 The World Bank and the Peasant Problem Gavin Williams 16

3 Agricultural Policies in Mainland Tanzania, 1946-76 Andrew Coulson

4 Agricultural Development Policy in Kenya from the Colonial Period to 1975 Judith Heyer

5 Commodity Production in Kenya's Central Province Michael Cowen

6 Ghana, 1951-78: the Agrarian Basis of the Post-colonial State Bjorn Beckman

7 Agrarian Change in Northern Ghana: Public Investment, Capitalist Farming and Famine Andrew Shepherd

8 'Rural Development' and the Rural Economy in Niger, 1900-75 Pepe Roberts

9 Agricultural Policies in Nigeria, 1900-78 Tom Forrest

10 Cooperative Policy and Village Development in Northern Nigeria Roger King

11 The Kano River Project, Nigeria: the Impact of an Irrigation Scheme on Productivity and Welfare Tina Wallace

12 Evaluating the Gezira Scheme: Black Box or Pandora's Box Tony Barnett

13 The Senegal River Valley Adrian Adams 


\section{List of Maps}

1 Tanzania $\quad 54$

2 Central Kenya 91

3 Ghana 144

4 Niger Republic 194

5 Nigeria 223

6 Northern Nigeria, showing villages in study of credit and marketing cooperatives

7 The Gezira Scheme

263

8 The Senegal River Valley $\quad 346$ 


\section{Preface}

Research on problems of rural development in Africa and Asia has been a high priority at Queen Elizabeth House, Oxford, for some After years of neglect by governments and aid agencies alike, rural development emerged as the major policy approach of international agencies involved in the third world in the 1960s. Many large, government-organised, often foreign-financed projects were initiated. It soon became apparent, however, that these rural development projects were rarely successful and it was natural to ask why. This simple and obvious question led to the series of discussions and exchanges which culminated in this book.

It was decided to focus on Africa and to bring together researchers involved in a series of studies that hopefully would help us to understand why failure was so common and success so rare in rural development. Our initial proposal was for a series on 'African rural development projects observed'. An informal seminar was held at Queen Elizabeth House in July 1977 which was attended by people who had studied, and in many cases been engaged in, implementing rural development policies and projects. At the seminar it was agreed to put together a collaborative, multi-disciplinary study of African projects and policies. Each author was asked to examine the most striking problems and contradictions in the theory and practice of rural development which emerged in the discussions in the seminar but was of course free to reach his own conclusions.

The book covers seven countries, three in East Africa (Kenya, Tanzania and the Sudan) and four in West Africa (Ghana, Niger, Nigeria and Senegal). The thirteen chapters contain a wealth of material which indicates clearly that irrigation projects and settlement schemes usually have not even met their production goals. More generally, government policies and projects have tended to increase inequality and have had little impact on reducing rural poverty. More often than not, the government has represented interests other than those of the rural poor and it is hardly surprising, therefore, that public intervention has in practice been harmful to the majority of rural people rather than beneficial. 
As the Warden of Queen Elizabeth House it was my privilege to sponsor this work and provide modest facilities. The African Studies Committee of the University of Oxford and the George Webb Medley Fund gave financial support to cover some of the expenses of the seminar. In addition to the authors of the chapters, the following also attended the seminar and contributed to the discussions: Raymond Apthorpe, Ian Carruthers, Paul Clough, Tim Dottridge, Eve Hall, Jocelyn Jones, Richard Palmer-Jones, Andrew Pearse, Chris Robbins, Terry Spens, and Anne Whitehead. Daphne Snell helped organise the seminar and subsequently assisted in typing the papers; Louise Henry and Muriel Knowles also helped type papers and prepare the final manuscript.

Magdalen College, Oxford

KEITH GRIFFIN 24 December 1979 


\section{Notes on the Contributors}

Judith Heyer is an economist at Somerville College, and at Queen Elizabeth House, Oxford. She taught for many years at the University of Nairobi.

Pepe Roberts is a social anthropologist. She teaches in the Department of Sociology at the University of Liverpool. She has carried out research in Ghana, Nigeria and Niger.

Gavin Williams teaches politics and sociology at St Peter's College, Oxford, and is a Research Associate at Queen Elizabeth House. He has carried out research in Nigeria.

Andrew Coulson is an economist at the Project Planning Centre, University of Bradford. He worked for several years in Tanzania.

Michael Cowen is an economist at the Centre for Development Studies, University College, Swansea. He has carried out research in Kenya for many years.

Bjorn Beckman teaches political economy in the Department of Politics, Ahmadu Bello University, Zaria. He has carried out research in Ghana, and has for many years been attached to the Scandinavian Institute for African Studies at Uppsala.

Andrew Shepherd is a sociologist at the Institute of Local Government, University of Birmingham. He recently completed his doctoral thesis on Ghana for the University of Cambridge.

Tom Forrest is an economist, who has taught for several years at Ahmadu Bello University, Zaria, and has recently been a Visiting Fellow at Queen Elizabeth House, Oxford. 
Roger King is an economist based in Reading, who has carried out research in Nigeria and elsewhere in West Africa.

Tina Wallace is a sociologist at the Department of Research and Consultancy, Ahmadu Bello University, Zaria. She completed her doctorate for Makerere University, and carried out research at the Centre for Social and Economic Research, Ahmadu Bello University.

Tony Barnett is a sociologist at the School of Development Studies, University of East Anglia, Norwich. He has worked and carried out research in several countries, including Sudan, Eritrea and Papua New Guinea.

Adrian Adams lives and writes in Senegal. She formerly taught anthropology in the Department of Sociology, University of Aberdeen. 